\title{
Pola makan dan hubungannya dengan kejadian stroke di RSUD dr. Doris Sylvanus Palangka Raya
}

\author{
Eating pattern and its association with prevalence of stroke at dr. Doris Sylvanus Hospital \\ Palangka Raya
}

Perawaty ${ }^{1}$ Pernodjo Dahlan ${ }^{2}$, Herni Astuti ${ }^{3}$

\begin{abstract}
Background: According to WHO it is estimated that there are 15 million people having stroke annually. High prevalence of stroke happens at Kalimantan Tengah as indicated from the growing number of outpatients and inpatients of stroke every year. There is a shift in eating pattern at urban areas from traditional eating pattern to western eating pattern that has high composition of calories, protein, fat, sugar and less fibre causing nonproportional nutrient intake. This condition is a risk factor for the prevalence of degenerative diseases such as hypertension, coronary heart disease and other health problems. Efforts for primary prevention against stroke can be made through intervention in unhealthy lifestyle including eating pattern.

Objectives: To identify association between eating pattern and the prevalence of stroke at dr. Doris Sylvanus Hospital Palangka Raya.

Methods: The study was analytic observational with case control design. Subject consisted of cases and control at comparison 1:1 matched in age. Cases were stroke inpatients of dr. Doris Sylvanus Hospital and control group consisted of patients of other diseases at the same hospital. The study involved 76 patients taken concecutive. Data comprised of sample identity, waist circumference, eating pattern, hypertension, physical activity and smoking habit. Data of eating pattern were obtained through semi quantitative food frequency questionnaire. The result of the study was analyzed using chi square and logistic regression.

Results: The result of the study showed there were 5 variables significantly associated with the prevalence of stroke; ie. more consumption of processed foods (OR 7,53 C/ 95\% : 1,38-41,13), less consumption of fruits (OR 6,98 Cl 95\%, 1,53-31,80), less consumption of fish (OR 6,36 Cl 95\% : 1,15 - 34,99), hypertension (OR $10,91 \mathrm{Cl} 95 \%, 2,43-49,03)$ and less physical activities (OR 8,36 Cl 95\%, 1,72-40,56) while the frequency of fast foods, alcohol consumption, obesity and smoking are not statistically significant $(p>0.05)$.

Conclusions: The presence of hypertension, less physical activity, more consumption of processes foods, less consumption of fruits and less consumption of fish a risk factor for the dominant influence on the incidence of stroke.
\end{abstract}

KEYWORDS: stroke, eating pattern, case control

\begin{abstract}
ABSTRAK
Latar belakang: Laporan World Health Organization (WHO), diperkirakan setiap tahun terdapat 15 juta orang di seluruh dunia yang mengalami stroke. Tingginya prevalensi stroke di Kalimantan Tengah dilihat dari penderita rawat inap dan rawat jalan di rumah sakit yang jumlahnya meningkat setiap tahun. Terjadinya pergeseran pola makan di kota-kota besar dari pola makan tradisional ke pola makan barat yang komposisinya terlalu tinggi kalori, banyak protein, lemak, gula tetapi rendah serat menimbulkan ketidakseimbangan asupan zat gizi. Kondisi tersebut merupakan faktor risiko untuk terjadinya penyakit degeneratif seperti hipertensi, jantung koroner dan masalah kesehatan lainnya. Upaya pencegahan tingkat awal atau preventif primer pada stroke dapat dilakukan dengan intervensi pada gaya hidup yang tidak sehat termasuk pola makan.
\end{abstract}

\footnotetext{
${ }^{1}$ Poltekkes Kemenkes Palangka Raya, Jalan George Obos No. 30, 32 Palangka Raya 73111 - Kalimantan Tengah. ${ }^{2}$ Bagian IImu Penyakit Syaraf, Fakultas Kedokteran UGM, JI. Farmako, Sekip Utara, Yogyakarta 55281.

${ }^{3}$ Bagian Gizi RSUP Dr. Sardjito, JI. Kesehatan No 1, Yogyakarta.
} 
Tujuan: Untuk mengetahui hubungan pola makan dengan kejadian stroke di RSUD dr. Doris Sylvanus Palangka Raya.

Metode: Penelitian ini merupakan penelitian observasional analitik menggunakan rancangan case control. Subjek terdiri dari kasus dan kontrol dengan perbandingan 1:1 yang telah dilakukan matching terhadap umur. Kasus adalah penderita stroke dan kontrol adalah penderita penyakit lainnya yang menjalani rawat inap di RSUD dr. Doris Sylvanus Palangka Raya. Jumlah subjek adalah 76 orang yang ditentukan dengan metode consecutive sampling. Data yang dikumpulkan yaitu identitas sampel, lingkar pinggang, pola makan, hipertensi, aktifitas fisik dan merokok. Data pola makan dikumpulkan dengan formulir semi quantitatif food frequency. Hasil penelitian dianalisis dengan menggunakan Chi square dan regresi logistik.

Hasil: Hasil penelitian menunjukkan terdapat 5 variabel yang berhubungan signifikan dengan kejadian stroke yaitu lebih konsumsi makanan olahan (OR 7,53 Cl 95\% : 1,38 - 41,13), kurang konsumsi buah (OR 6,98 Cl 95\% : 1,53 - 31,80), kurang konsumsi ikan (OR 6,36 Cl 95\% : 1,15 - 34,99), hipertensi (OR 10,91 Cl 95\% : 2,43 - 49,03) dan kurang aktivitas fisik (OR 8,36 Cl 95\% : 1,72 - 40,56), sedangkan frekuensi konsumsi fast food, konsumsi sayuran berwarna, konsumsi alkohol, obesitas, dan merokok tidak signifikan secara statistik ( $p>0,05)$.

Kesimpulan: Adanya hipertensi, kurang aktivitas fisik, lebih konsumsi makanan olahan, kurang konsumsi buah dan kurang konsumsi ikan merupakan faktor risiko terhadap kejadian stroke.

KATA KUNCI: stroke, pola makan, case control

\section{PENDAHULUAN}

Menurut laporan World Health Organization (WHO), diperkirakan setiap tahun terdapat 15 juta orang di seluruh dunia yang mengalami stroke dan dari jumlah tersebut terdapat kurang lebih 5 juta orang meninggal dan 5 juta mengalami kecacatan permanen akibat gejala sisa stroke dan menjadi beban keluarga. Insiden stroke di negara berkembang cenderung meningkat. Stroke merupakan penyebab kematian nomor 3 terbesar setelah penyakitjantung dan kanker terutama di negara-negara industri atau negara maju (1). Prevalensi stroke, berdasarkan diagnosis oleh tenaga kesehatan atau gejala yang menyerupai stroke di Indonesia adalah $0,8 \%$ dan di Kalimantan Tengah adalah $0,53 \%$. Menurut kabupaten/kota di Provinsi Kalimantan Tengah, prevalensi stroke berkisar antara $0,21 \%-1,58 \%$ dan Kota Palangka Raya mempunyai prevalensi stroke sebesar 0,85\% (2).Tingginya prevalensi stroke di Kalimantan Tengah juga bisa dilihat dari jumlah penderita rawat inap dan rawat jalan di rumah sakit yang jumlahnya meningkat setiap tahun. Data laporan tahunan RSUD dr. Doris Sylvanus Palangka Raya menunjukkan jumlah penderita stroke rawat jalan berjumlah 216 orang tahun 2006, meningkat menjadi 273 orang tahun 2008 , sedangkan penderita stroke yang menjalani rawat inap pada tahun 2006 berjumlah 242 orang dan meningkat menjadi 323 orang pada tahun 2008 (3).
Pesatnya perkembangan pembangunan berdampak pada perubahan gaya hidup dan pola makan di Indonesia. Hasil Susenas tahun 2003 memperlihatkan adanya perbedaan pola makan antara masyarakat perkotaan dan pedesaan. Pada masyarakat perkotaan telah terdapat kecenderungan untuk mengonsumsi makanan siap saji (4).Terjadinya pergeseran pola makan di kota-kota besar dari pola makan tradisional ke pola makan barat yang komposisinya terlalu tinggi kalori, banyak protein, lemak, gula tetapi rendah serat menimbulkan ketidakseimbangan asupan zat gizi. Kondisi tersebut merupakan faktor risiko untuk terjadinya penyakit degeneratif seperti hipertensi, jantung koroner dan masalah kesehatan lainnya.

Upaya pencegahan tingkat awal atau preventif primer pada stroke dapat dilakukan dengan intervensi pada gaya hidup yang tidak sehat termasuk pola makan. Beberapa studi prospektif telah melaporkan kemungkinan efek perlindungan dari konsumsi sayuran dan buah terhadap stroke. Satu penelitian di Jepang menunjukkan bahwa sayuran dan buahbuahan dapat melindungi terhadap kejadian cerebral infark serta hemorrhagic stroke (5). Suatu penelitian kohort prospektif menemukan bahwa mengonsumsi ikan 1 kali perbulan atau lebih dapat mengurangi stroke iskemik pada pria (6). Pengendalian tekanan darah, pengaturan pola makan, pengurangan konsumsi alkohol serta aktivitas fisik yang teratur merupakan faktor penting dalam pencegahan stroke. 


\section{BAHAN DAN METODE}

Jenis penelitian ini adalah penelitian observasional analitik menggunakan rancangan case control (7). Penelitian dilakukan di RSUD dr. Doris Sylvanus Palangka Raya dan dilaksanakan selama 5 bulan yaitu mulai bulan November 2009 sampai dengan Maret 2010.

Populasi penelitian adalah seluruh pasien stroke yang di rawat di RSUD dr. Doris Sylvanus Palangka Raya. Sampel penelitian adalah pasien stroke yang memenuhi kriteria inklusi dan ekslusi. Sampel pada penelitian ini berjumlah 76 orang terdiri dari 38 orang untuk kelompok kasus dan 38 orang untuk kelompok kontrol.

Variabel pada penelitian ini adalah variabel bebas/ independen : pola makan dan variabel terikat adalah stroke.

Data primer meliputi lingkar pinggang, hipertensi, aktivitas fisik, merokok dan pola makan. Data sekunder meliputi data identitas awal dan diagnosis penyakit penderita. Pengumpulan data dilakukan oleh peneliti yang dibantu oleh tenaga enumerator alumni Jurusan Gizi Poltekkes Kemenkes Palangka Raya yang telah dilatih. Pengukuran lingkar pinggang menggunakan pita lingkar pinggang dan pola makan menggunakan formulir semi quantitatif food frequency (SQFF).

Setelah data terkumpul dilakukan editing dan coding kemudian dianalisis. Data dianalisis univariat, bivariat dan multivariat. Uji statistik menggunakan Chi square dan regresi logistik.
HASIL

\section{Karakteristik subjek penelitian}

Rata-rata umur subjek penelitian adalah 49,6 tahun (SD $\pm 8,97$ ). Sebanyak $46,1 \%$ subjek penelitian memiliki tingkat pendidikan sedang. Berdasarkan jenis pekerjaan paling banyak subjek memiliki pekerjaan PNS dan swasta yaitu 32 orang $(42,1 \%)$. Hasil uji statistik kai kuadrat menunjukkan tidak terdapat perbedaan yang signifikan antara tingkat pendidikan atau jenis pekerjaan kasus dan kontrol $(p>0,05)$. Distribusi kasus dan kontrol dapat dilihat pada Tabel 1.

\section{Hubungan pola makan dengan kejadian stroke}

Frekuensi konsumsi makanan yang meliputi frekuensi konsumsi makanan olahan, fast food, sayuran berwarna, buah, ikan dan alkohol yang diperoleh melalui wawancara dengan SQFF dikategorikan menjadi dua yaitu lebih dan cukup untuk makanan olahan dan fast food. Untuk konsumsi sayuran bewarna, buah dan ikan dikategorikan menjadi dua yaitu kurang dan cukup. Konsumsi alkohol dikategorikan menjadi dua yaitu ya dan tidak. Hasil uji statistik menunjukkan terdapat hubungan yang signifikan pada frekuensi konsumsi makanan olahan, sayuran berwarna, buah dan ikan $(p<0,05)$, sedangkan frekuensi konsumsi fast food dan konsumsi alkohol tidak berhubungan secara signifikan $(p>0,05)$.

Tabel 1. Distribusi frekuensi subjek penelitian

\begin{tabular}{lcccc}
\hline \multirow{2}{*}{ Karakteristik } & Kasus & Kontrol & Jumlah & \multirow{2}{*}{$\boldsymbol{p}$} \\
\cline { 2 - 4 } & $\mathbf{n ( \% )}$ & $\mathbf{n ~ ( \% )}$ & $\mathbf{n ~ ( \% )}$ & \\
\hline Kelompok umur & & & & \\
$\quad \leq 49$ tahun & $16(42,1 \%)$ & $21(55,3 \%)$ & $37(48,7 \%)$ & 0.251 \\
$\quad>49$ tahun & $22(57,9 \%)$ & $17(44,7 \%)$ & $39(51,3 \%)$ & \\
$\begin{array}{l}\text { Jenis kelamin } \\
\quad \text { Laki-laki }\end{array}$ & $21(55,3 \%)$ & $19(50 \%)$ & $40(52,6 \%)$ & 0.646 \\
$\quad$ Perempuan & $17(44,7 \%)$ & $19(50 \%)$ & $36(47,4 \%)$ & \\
Pendidikan & & & & \\
$\quad$ Rendah & $12(31,6 \%)$ & $5(13,2 \%)$ & $17(22,4 \%)$ & 0.110 \\
$\quad$ Sedang & $17(44,7 \%)$ & $18(47,4 \%)$ & $35(46,1 \%)$ & \\
$\quad$ Tinggi & $9(23,7 \%)$ & $15(39,5 \%)$ & $24(31,6 \%)$ & \\
Pekerjaan & & & & \\
$\quad$ PNS & $13(34,2 \%)$ & $19(50,0 \%)$ & $32(42,1 \%)$ & 0.061 \\
$\quad$ Swasta & $21(55,3 \%)$ & $11(28,9 \%)$ & $32(42,1 \%)$ & \\
$\quad$ Tidak bekerja & $4(10,5 \%)$ & $8(21,1 \%)$ & $12(15,8 \%)$ & \\
\hline
\end{tabular}




\section{Hubungan frekuensi konsumsi makanan olahan dengan kejadian stroke}

Makanan olahan yang sering dikonsumsi subjek penelitian adalah garam dapur, kecap, saos tomat, sosis, corned beef, telur asin, ikan asin, bakso, dan penyedap rasa. Ditinjau dari frekuensi konsumsi makanan olahan, terdapat hubungan yang signifikan antara faktor risiko frekuensi konsumsi makanan olahan dengan kejadian stroke $(p<0,05)$ dengan nilai $\mathrm{OR}=3,29 ; 95 \% \mathrm{Cl}=1,17-$ 9,40 apabila frekuensi konsumsi makanan olahan kasus dibandingkan dengan kontrol (Tabel 2).

\section{Hubungan frekuensi konsumsi fast food dengan kejadian stroke}

Berdasarkan hasil uji statistik, tidak terdapat hubungan yang signifikan antara frekuensi konsumsi fast food dengan kejadian stroke $(p>0,05)$. Tetapi orang yang memiliki frekuensi konsumsi fast food dengan kategori lebih memiliki risiko 2,58 kali lebih besar untuk terjadinya stroke dibandingkan orang yang frekuensi konsumsi fast food cukup, selengkapnya dapat dilihat pada Tabel 3.
Hubungan frekuensi konsumsi sayuran berwarna dengan kejadian stroke

Ditinjau dari frekuensi konsumsi sayuran berwarna terlihat adanya hubungan yang signifikan pada frekuensi konsumsi sayuran berwarna antara kasus dan kontrol $(p<0,05)$. Hasil uji statistik menunjukkan bahwa orang dengan frekuensi konsumsi sayuran berwarna kurang memiliki risiko 4,17 kali lebih besar terhadap stroke dibandingkan dengan orang yang frekuensi konsumsi sayuran berwarna cukup (OR 4,17; 95\% Cl : 1,45-12,15) (Tabel 4).

\section{Hubungan frekuensi konsumsi buah dengan kejadian stroke}

Pada frekuensi konsumsi buah, terdapat hubungan konsumsi buah pada kasus dan kontrol $(p<0,05)$. Frekuensi konsumsi buah merupakan faktor risiko terhadap kejadian stroke, orang dengan frekuensi konsumsi buah kurang memiliki risiko 5,52 kali lebih besar terhadap stroke dibandingkan dengan orang yang frekuensi konsumsi buahnya cukup (OR: 5.52; 95\% Cl: 1,84 - 17,05) (Tabel 5).

Tabel 2. Hubungan frekuensi konsumsi makanan olahan dengan kejadian stroke

\begin{tabular}{lcccc}
\hline \multirow{2}{*}{ Variabel } & Kasus & Kontrol & $\mathbf{p}$ & OR \\
\cline { 2 - 5 } & $\mathbf{n ~ ( \% )}$ & $\mathbf{n ~ ( \% )}$ & & $\mathbf{( 9 5 \% ~ C l )}$ \\
\hline Makanan olahan & & & & \\
Lebih & $25(65,8 \%)$ & $14(36,8 \%)$ & 0,012 & 3,29 \\
Cukup & $13(34,2 \%)$ & $24(63,2 \%)$ & & $1,17-9,40$ \\
\hline
\end{tabular}

Tabel 3. Hubungan frekuensi konsumsi fast food dengan kejadian stroke

\begin{tabular}{lcccc}
\hline \multirow{2}{*}{ Variabel } & Kasus & Kontrol & $\boldsymbol{p}$ & OR \\
\cline { 2 - 5 } & $\mathbf{n ~ ( \% )}$ & $\mathbf{n ~ ( \% )}$ & & $\mathbf{( 9 5 \% ~ C l )}$ \\
\hline Fast food & & & & \\
Lebih & $31(81,6 \%)$ & $24(63,2 \%)$ & 0.073 & 2.58 \\
Cukup & $7(18,4 \%)$ & $14(36,8 \%)$ & & $0.81-8.72$ \\
\hline
\end{tabular}

Tabel 4. Hubungan frekuensi konsumsi sayuran berwarna dengan kejadian stroke

\begin{tabular}{lcccc}
\hline \multirow{2}{*}{ Variabel } & Kasus & Kontrol & $\boldsymbol{p}$ & OR \\
\cline { 2 - 5 } & $\mathbf{n ~ ( \% )}$ & $\mathbf{n ~ ( \% )}$ & & $\mathbf{( 9 5 \% ~ C l )}$ \\
\hline $\begin{array}{l}\text { Sayuran berwarna } \\
\text { Kurang }\end{array}$ & $25(65,8 \%)$ & $12(31,6 \%)$ & 0,003 & 4,17 \\
Cukup & $13(34,2 \%)$ & $26(68,4 \%)$ & & $1,45-12,15$ \\
\hline
\end{tabular}




\section{Hubungan frekuensi konsumsi ikan dengan kejadian stroke}

Ditinjau dari frekuensi konsumsi ikan (Tabel 6), terlihat adanya hubungan yang signifikan pada frekuensi konsumsi ikan antara kasus dan kontrol $(p<0,05)$. Hasil uji statistik menunjukkan bahwa orang dengan frekuensi konsumsi ikan kurang memiliki risiko 3,38 kali lebih besar terhadap stroke dibandingkan dengan orang yang frekuensi konsumsi ikan cukup (OR 3,38; 95\% Cl:1,18 9,81).

\section{Hubungan frekuensi konsumsi alkohol dengan kejadian stroke}

Konsumsi alkohol pada subjek penelitian dinilai berdasarkan ada tidaknya subjek penelitian mengonsumsi alkohol dalam 3 bulan terakhir. Uji statistik kai kuadrat menunjukkan tidak terdapat perbedaan proporsi konsumsi alkohol pada kasus dengan kontrol $(p>0,05)$.

Berdasarkan Tabel 7, hasil analisis statistik kai kuadrat menunjukkan bahwa faktor risiko konsumsi alkohol tidak berhubungan signifikan dengan kejadian stroke pada kasus dan kontrol ( $p$ $>0,05$ ), tetapi orang yang mengonsumsi alkohol memiliki risiko 2,36 kali lebih besar untuk terkena stroke dibandingkan orang yang tidak mengonsumsi alkohol (OR : 2,36; 95\% Cl : 0,85-6,58).

\section{Hubungan faktor risiko lain dengan kejadian stroke}

Obesitas pada subjek penelitian dinilai berdasarkan obesitas sentral dengan lingkar pinggang (waist circumference). Obesitas sentral dikategorikan menjadi dua yaitu obes jika lingkar pinggang $>80 \mathrm{~cm}$ pada wanita dan $>90 \mathrm{~cm}$ untuk laki-laki dan tidak obes jika lingkar pinggang $\leq 80$ $\mathrm{cm}$ pada wanita dan $\leq 90 \mathrm{~cm}$ untuk laki-laki. Hasil uji statistik menunjukkan terdapat hubungan antara obesitas dengan kejadian stroke $(p<0,05)$. Orang dengan obesitas memiliki risiko 3,46 kali lebih besar terhadap stroke dibandingkan dengan orang yang tidak obesitas (Tabel 8).

Hipertensi pada subjek penelitian juga dinilai berdasarkan ada tidaknya hipertensi melalui pengukuran tekanan darah. Uji statistik kai kuadrat menunjukkan bahwa ada hubungan antara hipertensi dengan penyakit stroke pada kasus dan kontrol $(p<$ $0,05)$. Pada Tabel 9 , hasil uji statistik menunjukkan terdapat hubungan antara hipertensi dengan kejadian stroke $(p<0,05)$. Orang dengan hipertensi memiliki risiko 12,4 kali lebih besar terhadap stroke dibandingkan dengan orang yang tidak hipertensi.

Aktivitas fisik pada kasus dan kontrol dibedakan menjadi dua kategori yaitu kurang dan cukup. Hasil uji statistik menunjukkan terdapat hubungan yang bermakna antara aktivitas fisik dengan kejadian

Tabel 5. Hubungan frekuensi konsumsi buah dengan kejadian stroke

\begin{tabular}{lcccc}
\hline \multirow{2}{*}{ Variabel } & Kasus & Kontrol & $\boldsymbol{p}$ & OR \\
\cline { 2 - 5 } & $\mathbf{n ~ ( \% )}$ & $\mathbf{n ~ ( \% )}$ & & $\mathbf{( 9 5 \% ~ C l )}$ \\
\hline Buah-buahan & $29(76,3 \%)$ & $14(36,8 \%)$ & 0,001 & 5,52 \\
Kurang & $9(23,7 \%)$ & $24(63,2 \%)$ & & $1,84-17,05$ \\
Cukup & &
\end{tabular}

Tabel 6. Hubungan frekuensi konsumsi ikan dengan kejadian stroke

\begin{tabular}{lcccc}
\hline \multirow{2}{*}{ Variabel } & Kasus & Kontrol & $\boldsymbol{p}$ & OR \\
\cline { 2 - 5 } & $\mathbf{n ~ ( \% )}$ & $\mathbf{n ~ ( \% )}$ & & $\mathbf{( 9 5 \%} \mathbf{~ C l )}$ \\
\hline Ikan & & & & \\
Kurang & $27(71,1 \%)$ & $16(42,1 \%)$ & 0,011 & 3,38 \\
Cukup & $11(28,9 \%)$ & $22(57,9 \%)$ & & $1,18-9,81$ \\
\hline
\end{tabular}

Tabel 7. Hubungan frekuensi konsumsi akohol dengan kejadian stroke

\begin{tabular}{lcccc}
\hline \multirow{2}{*}{ Variabel } & Kasus & Kontrol & $\mathbf{p}$ & OR \\
\cline { 2 - 5 } & $\mathbf{n ~ ( \% )}$ & $\mathbf{n ~ ( \% )}$ & & $\mathbf{( 9 5 \% ~ C l )}$ \\
\hline Alkohol & & & & \\
Ya & $24(63,2 \%)$ & $16(42,1 \%)$ & 0,066 & 2,36 \\
Tidak & $14(36,8 \%)$ & $22(57,9 \%)$ & & $0,85-6,58$ \\
\hline
\end{tabular}


stroke $(p<0,05)$. Orang dengan aktivitas fisik yang kurang memiliki risiko 3,46 kali lebih besar terhadap stroke dibandingkan dengan orang dengan aktivitas fisik cukup (Tabel 10).

Merokok pada kasus dan kontrol dibedakan menjadi dua kategori yaitu ya dan tidak. Tabel 11 menunjukkan bahwa hasil analisis statistik bivariat terhadap faktor risiko merokok diperoleh OR 1,63 (95\% Cl: 0,55-4,91) dan $p=0,324$ tidak bermakna secara statistik. Hal ini menunjukkan bahwa subjek penelitian yang merokok memiliki risiko 1,63 kali lebih besar untuk menderita stroke dibandingkan dengan subjek penelitian yang tidak merokok, tetapi secara statistik menunjukkan hubungan yang tidak bermakna $(p>0,05)$.

\section{Faktor risiko dominan yang berhubungan dengan kejadian stroke}

Berdasarkan analisis regresi logistik, Tabel 12 memperlihatkan bahwa terdapat 5 variabel yang memiliki hubungan bermakna secara statistik dengan kejadian stroke $(p<0,05)$, yaitu variabel lebih konsumsi makanan olahan, kurang konsumsi buah, kurang konsumsi ikan, hipertensi dan kurang aktivitas fisik.

Tabel 8. Hubungan obesitas dengan kejadian stroke

\begin{tabular}{|c|c|c|c|c|}
\hline Variabel & $\begin{array}{c}\text { Kasus } \\
\text { n (\%) }\end{array}$ & $\begin{array}{c}\text { Kontrol } \\
\mathrm{n}(\%)\end{array}$ & $p$ & $\begin{array}{c}\text { OR } \\
(95 \% \mathrm{Cl})\end{array}$ \\
\hline \multicolumn{5}{|l|}{ Lingkar pinggang } \\
\hline Obesitas & $20(52,6 \%)$ & $10(26,3 \%)$ & 0,010 & 3,46 \\
\hline Tidak Obesitas & $17(44,7 \%)$ & $28(73,7 \%)$ & & $1,19-10,23$ \\
\hline
\end{tabular}

Tabel 9. Hubungan hipertensi dengan kejadian stroke

\begin{tabular}{|c|c|c|c|c|}
\hline \multirow{2}{*}{ Variabel } & Kasus & Kontrol & \multirow{2}{*}{$p$} & OR \\
\hline & $\mathrm{n}(\%)$ & n (\%) & & $(95 \% \mathrm{CI})$ \\
\hline \multicolumn{5}{|l|}{ Hipertensi } \\
\hline Hipertensi & $28(73,7 \%)$ & $7(18,4 \%)$ & 0.000 & 12.4 \\
\hline Tidak Hipertensi & $10(26,3 \%)$ & $31(81,6 \%)$ & & $3.72-43.24$ \\
\hline
\end{tabular}

Tabel 10. Hubungan aktivitas fisik dengan kejadian stroke

\begin{tabular}{|c|c|c|c|c|}
\hline Variabel & $\begin{array}{c}\text { Kasus } \\
n(\%)\end{array}$ & $\begin{array}{c}\text { Kontrol } \\
\mathrm{n}(\%)\end{array}$ & $p$ & $\begin{array}{c}\text { OR } \\
(95 \% \mathrm{Cl})\end{array}$ \\
\hline Aktivitas fisik & & & & \\
\hline Kurang & $21(55,3 \%)$ & $10(26,3 \%)$ & 0,010 & 3,46 \\
\hline Cukup & $17(44,7 \%)$ & $28(73,7 \%)$ & & $1,19-10,23$ \\
\hline
\end{tabular}

Tabel 11. Hubungan merokok dengan kejadian stroke

\begin{tabular}{|c|c|c|c|c|}
\hline Variabel & $\begin{array}{c}\text { Kasus } \\
\mathrm{n}(\%)\end{array}$ & $\begin{array}{c}\text { Kontrol } \\
n(\%)\end{array}$ & $p$ & $\begin{array}{c}\text { OR } \\
(95 \% \mathrm{Cl})\end{array}$ \\
\hline \multicolumn{5}{|l|}{ Merokok } \\
\hline $\mathrm{Ya}$ & $14(36,8 \%)$ & $10(26,3 \%)$ & 0,324 & 1,63 \\
\hline Tidak & $24(63,2 \%)$ & $28(73,7 \%)$ & & $0,55-4,91$ \\
\hline
\end{tabular}

Tabel 12. Hasil analisis multivariat faktor-faktor yang berhubungan dengan kejadian stroke

\begin{tabular}{lccc}
\hline \multicolumn{1}{c}{ Variabel } & $\boldsymbol{p}$ & $\begin{array}{c}\text { Exp } \\
\text { (B) }\end{array}$ & $\mathbf{9 5 \%} \mathbf{~ C l}$ \\
\hline Lebih konsumsi makanan olahan & 0,020 & 7.53 & $1,38-41,13$ \\
Kurang konsumsi buah & 0,012 & 6,98 & $1,53-31,80$ \\
Kurang konsumsi ikan & 0,034 & 6,36 & $1,15-34,99$ \\
Hipertensi & 0,002 & 10,91 & $2,43-49,03$ \\
Kurang aktivitas fisik & 0,008 & 8,36 & $1,72-40,56$ \\
\hline
\end{tabular}




\section{BAHASAN}

\section{Karakteristik subjek penelitian}

Berdasarkan hasil penelitian, 21 orang $(55,3 \%)$ kasus berjenis kelamin laki-laki dan 17 orang $(44,7 \%)$ perempuan. Hasil penelitian ini sejalan dengan penelitian di wilayah Bogor yang menunjukkan bahwa $76 \%$ penderita stroke di wilayah tersebut adalah laki-laki (8). Ditinjau dari segi umur rata-rata umur kasus adalah 49,6 tahun (SD $\pm 8,97)$. Menurut Kameyana, makin lanjut umur, makin meningkat pula kejadian infark dan perdarahan serebral. Risiko terjadinya infark pada dekade ke-6 sebanyak $26,6 \%$, pada dekade ke- 7 sebanyak $39,1 \%$ dan pada dekade ke-8 sebanyak $42,1 \%(9)$.

\section{Hubungan pola makan dengan kejadian stroke}

Hasil penelitian menunjukkan bahwa faktor frekuensi konsumsi makanan olahan secara statistik berhubungan signifikan $(p<0,05)$ dengan kejadian stroke (Tabel 2). Hasil penelitian ini sesuai dengan sebuah penelitian meta-analisis terhadap 13 penelitian kohort prospektif yang menemukan pasien dengan konsumsi garam yang tinggi, konsumsi makanan olahan yang meningkat mengalami risiko $23 \%$ lebih besar untuk terkena stroke dan $17 \%$ lebih besar untuk terkena penyakit jantung dibandingkan orang yang konsumsi garam dan makanan olahannya kurang setiap hari (10). Hasil penelitian ini juga sesuai sebuah penelitian meta-analisis terhadap penelitian prospektif yang diterbitkan dari tahun 1966 sampai 2008 disimpulkan bahwa konsumsi makanan yang mengandung garam tinggi secara signifikan meningkatkan risiko stroke dan penyakit kardiovaskuler. Mengurangi kebiasaan mengonsumsi makanan yang mengandung garam termasuk makanan yang diolah menggunakan garam akan menurunkan tekanan darah sistolik dan diastolik $7 / 4 \mathrm{mmHg}$ pada pasien dengan hipertensi dan $4 / 2 \mathrm{mmHg}$ pada pasien tanpa hipertensi (11).

Apabila dilihat dari frekuensi konsumsi fast food, menunjukkan bahwa frekuensi mengonsumsi fast food tidak berhubungan signifikan $(p<0,05)$ dengan kejadian stroke (Tabel 3). Namun orang dengan frekuensi konsumsi fast food lebih memiliki risiko lebih besar terhadap kejadian stroke dibandingkan dengan orang yang frekuensi konsumsi fast food cukup. Hasil penelitian ini berbeda dari berbagai penelitian dan kajian yang memperlihatkan bahwa penyebab tingginya kejadian stroke di negara berkembang adalah karena perubahan pola hidup dan pola konsumsi makanan. Kemajuan industri dan peningkatan status ekonomi di berbagai negara berkembang dihubungkan dengan gaya hidup perkotaan. Konsumsi makanan cepat saji dan inaktivitas fisik meningkat. Makanan cepat saji dihubungkan dengan kandungan natrium dan lemak jenuh yang tinggi (12).

Apabila dilihat dari frekuensi konsumsi sayuran berwarna, kasus yang kurang mengonsumsi sayuran berwarna sebanyak 29 orang $(76,3 \%)$. Hasil analisis bivariat menunjukkan bahwa faktor frekuensi konsumsi sayuran berwarna berhubungan signifikan $(p<0,05)$ dengan kejadian stroke, namun setelah dilakukan analisis multivariat frekuensi konsumsi sayuran berwarna tidak berhubungan dengan kejadian stroke (Tabel 4). Hasil penelitian ini berbeda dengan penelitian di Jepang yang menemukan hubungan antara asupan sayuran berwarna hijau dan kuning serta buah-buah terhadap risiko kematian karena stroke pada laki-laki dan perempuan. Dengan mengonsumsi sayuran berwarna hijau dan kuning serta buahbuahan mengurangi resiko terhadap stroke 20 - $40 \%$ baik pada laki-laki maupun perempuan (5). Penelitian yang dilakukan di Kabupaten dan Kota Jayapura menemukan bahwa kelompok yang jarang mengonsumsi pepaya dan jeruk manis dapat disimpulkan berhubungan dengan faktor risiko terjadinya stroke (13).

Pada frekuensi konsumsi buah, hasil analisis bivariat menunjukkan bahwa subjek penelitian dengan frekuensi konsumsi buah kurang memiliki risiko lebih besar untuk terkena stroke dibandingkan dengan subjek penelitian dengan frekuensi konsumsi buah cukup, secara statistik menunjukkan hubungan yang signifikan $(p<0,05)$ (Tabel 5). Pada analisis multivariat, frekuensi konsumsi buah juga merupakan faktor risiko stroke $(p<0,05)$ dengan OR:6,98 (95\% Cl:1,53-31,80). Penelitian ini sesuai dengan penelitian yang dilakukan oleh Johnsen et al., dengan meningkatkan asupan buah akan menurunkan terhadap risiko stroke iskemik (14). Hal ini juga sejalan dengan penelitian kohort prospektif yang menemukan bahwa konsumsi jus buah setiap hari dapat menurunkan risiko stroke (15). 
Sebuah penelitian di Kabupaten dan Kota Jayapura menemukan bahwa kelompok yang jarang mengonsumsi pepaya dan jeruk manis dapat disimpulkan berhubungan dengan faktor risiko terjadinya stroke (13).Sayuran dan buah-buahan mengandung berbagai zat gizi di antaranya vitamin, mineral minor, serat dan berbagai komponen aktif biologi. Komponen ini dikenal sebagai zat fitokimia yang mempunyai mekanisme melengkapi dan (komplemen) dalam aktivitas antioksidan, mengurangi agregasi trombosis, mengubah metabolisme kolesterol dan mengurangi tekanan darah (16).

Kalium mempunyai fungsi meningkatkan keteraturan denyut jantung, mengaktifkan kotraksi otot, dan membantu menurunkan tekanan darah. Konsumsi kalium yang memadai dapat mengurangi efek natrium dalam meningkatkan tekanan darah, dan secara bebas memberikan kontribusi terhadap penurunan risiko karena stroke. Satu penelitian menunjukkan bahwa bila seseorang menambahkan sepotong buah tinggi kalium ke dalam pola makanan sehari-hari, risiko terkena stroke fatal dapat dikurangi sebesar $40 \%$. Konsumsi ekstra kalium sebanyak $400 \mathrm{mg}$ setiap hari dapat mengurangi kemungkinan mendapat penyakit jantung dan pembuluh darah. Buah berwarna kuning kaya kandungan kalium, yang bermanfaat mencegah stroke dan jantung koroner, serta mencegah katarak. Sumber kalium banyak terdapat pada belimbing, nanas, pisang, belimbing buah, dan belimbing sayur (17).

Hasil analisis hubungan frekuensi konsumsi ikan dengan kejadian stroke menunjukkan ada hubungan yang signifikan antara frekuensi konsumsi ikan dengan kejadian stroke $(p<0,05)$ dan merupakan faktor risiko terhadap kejadian stroke (Tabel 6). Hasil analisis multivariat juga menunjukkan bahwa frekuensi konsumsi ikan memberi kontribusi yang besar terhadap kejadian stroke. Hasil penelitian ini sesuai dengan meta analisis dari beberapa penelitian kohort bahwa seseorang yang mengonsumsi ikan lebih sering mempunyai risiko kejadian stroke yang lebih kecil. Untuk orang yang mengonsumsi ikan satu kali perminggu mempunyai risiko untuk menderita stroke 0,87 kali lebih kecil diandingkan dengan yang mengonsumsi ikan satu kali per bulan (18).

Hasil penelitian ini juga sesuai dengan sebuah penelitian pada usia lanjut bahwa pada individu usia lanjut, mengonsumsi tuna atau ikan bakar atau ikan panggang berhubungan dengan risiko yang lebih rendah dari stroke iskemik, sedangkan asupan ikan goreng atau sandwich berhubungan dengan risiko yang lebih tinggi (19).Kejadian stroke iskemik secara signifikan dapat menurun dengan mengonsumsi ikan sedikitnya 1-3 kali per bulan. Ikan dapat lebih berpotensial untuk menurunkan kejadian stroke yaitu dengan cara pengolahan atau pemasakan yang baik sehingga kandungan asam lemak tak jenuh ganda atau omega 3 yang ada pada ikan yang berfungsi menurunkan risiko kejadian stroke dapat bekerja secara optimal. Kandungan omega 3 yang ada pada ikan juga dapat menurunkan tekanan darah, aritmia, profil lemak serta meningkatkan fungsi endothelial yang dapat menurunkan risiko terjadinya stroke terutama stroke iskemik. Selain itu konsumsi ikan juga dapat menurunkan tekanan darah yang merupakan salah satu faktor risiko kejadian stroke (18).

Mengonsumsi alkohol merupakan salah satu kebiasaan yang sering dijumpai di wilayah Kalimantan Tengah termasuk di daerah kabupaten dan kota Palangka Raya. Hasil penelitian ini menunjukkan sebanyak 24 orang $(63,2 \%)$ kasus penelitian pernah mengonsumsi alkohol dalam 3 bulan terakhir. Hasil analisis bivariat menunjukkan nilai OR 2,36 dengan $\mathrm{Cl}$ 95\%: 0,85-6,58 dan $p=0,066$ tidak bermakna secara statistik, dan setelah dilakukan analisis secara bersama-sama (multivariat) variabel konsumsi alkohol juga menunjukkan hubungan yang tidak bermakna dengan kejadian stroke $(p>0,05)$ (Tabel 7). Hasil penelitian ini sesuai dengan hasil penelitian yang mempelajari faktor risiko stroke pada ras kulit hitam Amerika dan hasilnya adalah bahwa konsumsi alkohol dengan jumlah sedikit pada kategori akut maupun kronis setelah dikontrol faktor merokok dan hipertensi menunjukkan hubungan yang tidak signifikan, adjusted odds ratio $=1,68$ dengan $95 \% \mathrm{Cl}$ $=0,84-3,35$ (20). Hasil penelitian ini sesuai dengan hasil di Jepang yang menemukan bahwa terdapat perbedaan risiko stroke antara peminum minuman keras setiap minggu dengan yang hanya sesekali mengonsumsi minuman keras (21). Penelitian ini juga sesuai dengan penelitian prospective cohort study terhadap 38.156 laki-laki tenaga kesehatan profesional di Amerika diperoleh hasil bahwa individu yang mengonsumsi alkohol dalam jumlah besar dan lebih dari dua kali perhari merupakan faktor risiko stroke iskemik (22). 


\section{Hubungan faktor risiko lain dengan kejadian stroke}

Ditinjau dari obesitas, hasil penelitian menunjukkan bahwa terdapat hubungan antara obesitas terhadap kejadian stroke $(p<0,05)$. Hasil analisis bivariat menunjukkan bahwa terdapat hubungan antara obesitas dengan kejadian stroke $(p<0,05)$ dengan $\mathrm{OR}=3,46$, artinya orang dengan kategori obesitas memiliki risiko 3,46 kali lebih besar untuk menderita stroke dibandingkan dengan orang yang tidak obes (Tabel 8). Setelah dilakukan analisis secara bersama-sama (multivariat) variabel obesitas menunjukkan hubungan yang tidak bermakna $(p>$ $0,05)$ Hasil penelitian ini berbeda dengan sebuah survei tindak lanjut terhadap 789 orang laki-laki berusia 54 tahun yang menderita stroke. Pada penelitian ini ukuran pinggang (obesitas abdominal), rasio lingkar pinggang panggul merupakan faktor risiko yang signifikan, sedangkan BMI bukan merupakan faktor risiko (23). Suatu penelitian di Taiwan menyatakan bahwa obesitas sentral merupakan prediksi yang lebih baik dibandingkan dengan IMT dan rasio lingkar pinggang/panggul, terhadap faktor risiko penyakit. Meskipun presentase lemak tubuh merupakan parameter yang berguna terhadap general obesity, risiko kesehatan lebih baik dan lebih mudah diprediksi dengan lingkar pinggang (24).

Ditinjau dari faktor risiko hipertensi, hasil analisis bivariat menunjukan nilai OR 12,4 dengan $\mathrm{Cl}$ 95\%: $3,72-43,24)$ dan $p=0,000$ bermakna secara statistik (Tabel 9). Artinya subjek penelitian dengan hipertensi memiliki risiko 12,4 kali lebih besar untuk terkena stroke dibandingkan dengan subjek penelitian yang tidak hipertensi. Pada analisis multivariat, faktor hipertensi tetap menunjukkan hubungan yang bermakna secara statistik dengan nilai OR 10,91 (95\% Cl : 2,43-49,03). Hal ini sejalan dengan hasil penelitian yang dilakukan di RS Adam Malik Medan yang meneliti faktor risiko stroke pada penderita yang dirawat di RS Adam Malik Medan, menemukan bahwa risiko stroke dengan angka OR terbesar adalah hipertensi (25).

Sebuah penelitian kasus kontrol yang dilakukan mulai tahun 1996 sampai 1997 menunjukkan penurunan tekanan darah berhubungan dengan penurunan risiko stroke sebesar $36 \%$ dan pada penderita $\mathrm{MCl}$ (miocard infarct) sebesar $27 \%$ setelah dilakukan follow up selama 4,5 tahun. Risiko stroke sejalan dengan peningkatan tekanan darah sistole, diastole maupun keduanya. Pada penelitian tersebut juga ditemukan bahwa hipertensi merupakan faktor risiko penderita $\mathrm{SNH}$ dengan $\mathrm{OR}=11,15, \mathrm{p}<0,001$. OR yang sangat tinggi ini kemungkinan dikarenakan penderita hipertensi tidak mendapat pengobatan secara teratur (9).

Hasil penelitian ini juga sesuai dengan penelitian yang dilakukan di Taiwan, melaporkan hasil bahwa hipertensi sebagai faktor risiko stroke iskemik ( $p=0,0083,95 \% \mathrm{Cl}: 1,2853-5,4608)$ (26). Beberapa jurnal yang menggunakan data NHANES (national health and nutrition examination survey) untuk mempelajari faktor risiko stroke pada ras kulit hitam Amerika, melaporkan hasil bahwa hipertensi adalah faktor risiko utama terjadinya stroke (20).Ditinjau dari aktivitas fisik, hasil penelitian menunjukkan bahwa terdapat perbedaan yang signifikan $(p<0,05)$ antara aktivitas kasus dan kontrol.

Tabel 10 menunjukkan orang yang aktivitas fisiknya kurang memiliki risiko 3,46 kali lebih besar terhadap stroke dibandingkan dengan orang dengan aktivitas fisik yang baik. Hasil penelitian ini sejalan dengan laporan WHO yang yang menjelaskan bahwa gaya hidup sedentary atau physical inactivity merupakan penyebab utama kematian dan terjadinya penyakit. Aktivitas fisik seperti olahraga yang dilakukan dengan prinsip FIT (frequency, intensity and time) dapat menurunkan risiko kematian karena penyakit jantung dan stroke, membantu mencegah serta menurunkan hipertensi dan dapat mengendalikan risiko obesitas sampai $50 \%$ (27). Penelitian tentang faktor risiko stroke pada kulit hitam Amerika melaporkan bahwa aktivitas yang rendah merupakan faktor risiko independen terhadap kejadian stroke dan diperoleh relative risk (RR) 2,07 dengan 95\%Cl:1,25-3,43 (20).

Berdasarkan hasil uji bivariat dan multivariat pada faktor risiko merokok menunjukkan tidak ada hubungan antara merokok dengan kejadian stroke tetapi orang yang merokok memiliki risiko 1,63 kali untuk terkena stroke dibandingkan orang yang tidak merokok (Tabel 11). Pada penelitian kasus kontrol menemukan bahwa merokok bukan merupakan faktor risiko stroke non hemoragik dengan OR:2 tetapi tidak bermakna $(p>0,05)$ sehingga merokok faktor prediksi terjadinya stroke non hemoragik (9). Hasil penelitian yang berbeda ditemukan pada metaanalisis dari 8 penelitian dengan rancangan kasus kontrol dan 2 penelitian dengan rancangan kohort 
secara keseluruhan ternyata ada bukti merokok merupakan faktor risiko terjadinya stroke (28).

\section{KESIMPULAN DAN SARAN}

Berdasarkan hasil penelitian dapat dibuat kesimpulan bahwa adanya hipertensi berhubungan dengan kejadian stroke. Kurang aktivitas fisik berhubungan dengan kejadian stroke. Konsumsi secara berlebihan makan olahan memiliki hubungan dengan kejadian stroke. Kurang konsumsi buah berhubungan dengan kejadian stroke. Konsumsi ikan berhubungan dengan kejadian stroke.

Berdasarkan kesimpulan di atas maka saran yang diberikan adalah perlu mengubah gaya hidup terutama yang berhubungan dengan faktor diet atau makanan dengan pola makan yang sehat dan mengonsumsi menu seimbang. Mengurangi atau membatasi konsumsi makanan olahan, menyertakan sayuran berwarna dan buah-buahan yang banyak mengandung antioksidan setiap waktu makan serta meningkatkan konsumsi ikan. Meningkatkan aktivitas fisik yang cukup dan teratur untuk mencegah peningkatan risiko stroke. Melakukan kontrol atau pemeriksaan tekanan darah secara teratur pada petugas atau unit pelayanan kesehatan terdekat serta mengendalikan berat badan. Perlu dilakukan penelitian lebih lanjut tentang hubungan konsumsi makanan olahan pada penderita stroke mengingat faktor tersebut pada analisis multivariat berkontribusi terhadap terjadinya stroke.

\section{RUJUKAN}

1. Mackay J, Mensah GA. The atlas of heart disease and stroke. New York: World Health Organization;2004.

2. Depkes RI. Riset kesehatan dasar 2007. Jakarta: Balitbangkes; 2008.

3. Anonim. Data Rekam Medik. Palangka Raya: RSUD dr. Doris Sylvanus Palangka Raya; 2008.

4. Atmarita. Nutrition problem in Indonesia. 2005 (Accessed June 15, 2009), [Available from: http://www.depkes.go.id].

5. Sauvaget C, Nagano J, Allen N, Kodama K. Vegetable and fruit intake and stroke mortality in The Hiroshima/Nagasaki Life Span Study. Stroke 2003;(34):2355-60.
6. He K, Rimm EB, Merchant A, Rosner BA, Stampfer MJ, Willett WC, Ascherio A. Fish consumption and risk of stroke in men. JAMA 2002;288(24):3130-6.

7. Suradi R, Siahaan CM, Boedjang RF, Sudiyanto, Setyaningsih I, Soedibjo S. Penelitian KasusKontrol. Jakarta: Sagung Seto; 2008.

8. Misbach J. Stroke morbidity in Bogor Area and Surroundings: A prospective observational analysis. Majalah Kedokteran Indonesia 2001;51(9):328-31.

9. Sukiman I, Weko DD. Faktor risiko pada stroke non hemoragik. Jurnal Nusantara 2001;34(1):1-6.

10. Wascher R. Salt (sodium) intake, stroke \& cardiovaskular disease. 2009. [accessed Jan 5 2011] [Tersedia dalam: http://ezinearticles. com].

11. Strazzullo P, D'Elia L, Kandala NB, Cappuccio FP. Salt intake, stroke, and cardiovascular disease: meta-analysis of prospective studies. BMJ 2009;339(4567):1-9.

12. Pinzon R. Setiap 6 detik nyawa melayang karena stroke. 2010 [Diakses 10 November 2010]. [Tersedia dalam: http://detikhealth.com], (), 2010.

13. Ali D. Hubungan pola makan dan konsumsi alkohol dengan kejadian Stroke di Kabupaten dan Kota Jayapura. Yogyakarta: Tesis, UGM; 2006.

14. Johnsen SP, Overpad K, Stripp C, Tjonneland A, Husted SE, Sorensen HT. Intake of fruit and vegetables and the risk of ischemic stroke in a cohort of Danish men and women. Am J Clin Nutr 2003;78:57-64.

15. Joshipura KJ, Ascherio A, Manson JE, Stampfer MJ, Rimm EB, Speizer FE, et al. Fruit and vegetable intake in relation to risk of ischemic stroke. Stroke 1999;282(13):1233-9.

16. Lipoeto NI. Zat gizi dan makanan pada penyakit kardiovaskuler. Padang: Andalas University Press; 2006.

17. Setiawan C. Manfaat buah mangga. 2008 [Diakses: 22 Desember 2010]. [Tersedia dalam: http://www.masenchipz.com].

18. He K, Song Y, Daviglus ML, Liu K, Horn LV, Dyer $A R$, et al. Fish consumption and incidence of stroke: a meta-analysis of cohort studies. Stroke 2004;35:1538-42. 
19. Mozaffarian D, Longstreth WT, Lemaitre RN, Manolio TA, Kuller LH, Burke GL, Siscovick DS. Fish consumption and stroke in ederly individuals: the cardiovaskular health study. Arch Intern Med 2005;165:200-6.

20. Gillium RF. Risk factors for stroke in blacks: review articles. Am J Epidemiology 1999;150(12):126674.

21. Iso H, Baba S, Mannami T, Sasaki S, Okada $\mathrm{K}$, Tsugane S, et al. JPHC study group, alcohol consumption and risk of stroke among middle aged men: the jphc study cohort I. Stroke 2004;35:1124-29.

22. Mukamal KJ, Asherio A, Mittleman MA, Conigrave KM, Camargo CA, Kawachi I, et al. Alcohol and risk for ischemic stroke in men : the role of drinking pattern and usual beverage. Ann Inter Med 2005;142(1):11-20.
23. Isozumi K. Obesity as a risk factor for cerebrovascular disease. Keio J Med 2004;53(1):7-11.

24. Kamso S. Dislipidemia dan obesitas sentral pada lanjut usia di Kota Padang. Jurnal Kesehatan Masyarakat Nasional 2007;2(2):73-7.

25. Siregar FA. Faktor risiko kejadian stroke penderita Rawat Inap RSUP Haji Adam Malik Medan. 2004 [Diakses tanggal 3 Juli 2009]. [Tersedia dalam: http://adln.lib.unair.ac.id].

26. Lee TH, Hsu WC, Chen CJ, Chen ST. Etiology study of young ischemic stroke in Taiwan. Stroke 2002;33:1950-5.

27. WHO. Global strategy on diet, physical activity and health. 2004 [Diakses tanggal 10 November 2010]. [Tersedia dalam:http://who.int].

28. Sasongko HA, Lamsudin R, Musfiroh $S$. Merokok sebagai faktor risiko stroke. Jurnal Berkala Neuro Sains 2001;2(3):143-51. 